\title{
Steady-State Academic Libraries: Retrenchment Solution?
}

\author{
DANIEL A. SAVAGE*
}

\section{INTRODUCTION}

Although retrenchment in Canadian academic libraries was seen as a passing phenomenon in the mid-1970's, in recent years it has become an accepted long-term mode of operation. According to "Cuts for Academic Libraries" (1986), Canadian university library budgets are under continued pressure after years of austerity. The Canadian Association of University Teachers (1987) warns that constant dollar expenditures between 1971 and 1984 have dropped $22.8 \%$ and acquisitions have dropped $29.5 \%$ per full-time equivalent student. Downs (1977) says that the good times of the 1960's were the anomaly and that retrenchment is merely a return to the status quo. According to Cochrane (1986) financial restraint in Canadian universities will continue for the rest of this century.

In seeking long-term solutions to problems of retrenchment in Jarger Canadian academic libraries, Denis and Auster at the University of Toronto have been investigating the management of retrenchment in larger Canadian academic libraries. Denis (1985) describes their work as one in which they are attempting to establish theoretical frameworks for decision-making in Canadian academic libraries in a retrenchment environment.

This author's research has been directed at retrenchment solutions in smaller Canadian universities. Nitecki (1984) proposes a positive rather than negative and passive attitude toward austerity, resulting in a search for practical solutions to economic retrenchment in smaller academic libraries. He (1984) states that in smaller academic libraries the steady-state or no growth collection development policy has merit. The intent of this paper is to investigate this type of library collection, where what is added equals what is removed, as a possible solution.

\section{THE PROBLEM AND WHY}

In these times of retrenchment, space shortages are being faced in most Canadian university libraries. The obvious solution is to prepare to construct more library space, however, smaller Canadian universities ought to take a look at steady-state theories. In considering this as a solution, the attitude that bigger is better must be carefully evaluated and the reluctance in most faculty and librarians to discard 
must change. The pivotal question that the smaller university is left with in evaluating steady-state theories, is "What should be available immediately on the shelves in the smaller university and what should be available elsewhere within a reasonable amount of time?"

\section{LITERATURE ON STEADY-STATE LIBRARY COLLECTIONS}

According to Gore (1976) the period 1967 to 1974 represented the biggest building boom in library history. Most expected that new buildings were going to solve all the space problems. Yet, in that same period, the space needed for burgeoning library collections grew even more quickly than the space being constructed. What is the solution now with very little library space being added?

Creaghe and Davis (1986) report average 1985 costs in the United States of $\$ 98.03$ per square foot to build new academic libraries. When considering the merits of the steady-state library collection concept, construction costs and the higher maintenance costs of larger collections should be calculated against the cost of withdrawing little-used items, placing them in storage, or shipping them to another lending centre. Creaghe and Davis (1986) calculate cost savings of $\$ 9.30$ per volume to construct a compact storage facility compared to $\$ 13.50$ for a conventional facility, as well as custodial-cost savings of over $\$ 200,000$ annually.

In the Atkinson Report (1976), the University Grants Committee in Great Britain published a report of a study they had conducted on capital provision for university libraries. The Committee questioned the long-held view of indefinite accumulation in academic library collections and recommended that the University Grants Committee adopt the principle of self-renewing libraries of limited growth. Without the introduction of this concept, nearly 85 percent of the 44 university libraries in Great Britain of concern to the Committee would have needed new buildings or extensions by 1985 .

In the United States, Gore (1976) edited a collection of essays which dealt with no-growth library collections and their viability. In this book Farber (1976) argues that in a college whose clientele is mainly undergraduate, the library should tailor its resources directly to the needs and character of its constituency. The major universities should maintain the research collections.

Watson (1978) states that the steady-state library collection concept is an attempt in academic library circles to deal with the three dilemmas of the need to cut costs, the need to limit indefinite expansion, and the need to improve the relevance and usefulness of library collections. He describes the steady-state library collection as one which changes to meet the needs of its clientele and changing situations, but does not grow.

After 15 years of retrenchment, those in smaller Canadian universities are realizing that their libraries cannot keep on growing indefinitely. They cannot afford the storage costs or the budgets to operate larger and larger academic libraries. In many cases, these library collections, when measured against the 
standards for university and college libraries, are already larger than that needed for the program they offer and the population they serve.

Smaller Canadian universities need to reconsider assumptions as to how long a book should remain in a library unused before it is removed. Trueswell (1976) has shown that as a general rule, approximately $80 \%$ of circulation requirements are satisfied by approximately $20 \%$ of a library's holdings. Kent (1979) in a study conducted at the University of Pittsburgh found that $40 \%$ of all books purchased by the university library during the period 1969 to 1975 were never used. Hall (1985) found that $27 \%$ of the collection of 141,000 items accounted for all circulation for the previous 12 months. Gore (1981) and Hardesty (1981) found the non-use percentage at their universities to be $40 \%$ and $60 \%$ respectively. This researcher found a non-use rate of $50 \%$ for new acquisitions from 1982-1985. Trueswell (1976) reported that if a book has not circulated in 12 years, it is not likely to ever circulate.

\section{DISADVANTAGES OF STEADY-STATE}

The steady-state library collection concept has been criticized for the inadequate data on which it is based. However, the argument can also be turned around. Where are the data that say bigger is better? And to what extent and at what cost is the co!lection better? In the small university offering predominately an undergraduate program there is surely a point in the size of the library collection beyond which the usage does not justify the expenditure.

Another criticism of the steady-state library collection concept is the cost involved in weeding, particularly in pulling catalogue cards or in changing location notations on them. However, with most Canadian academic libraries possessing computer produced microfiche catalogues, or on-line catalogues, the costs involved in editing computerized records are no more than that for a circulation.

Faculty opinion is also a factor militating against the steady-state library collection. All researchers would like immediate access to any library item desired, but these aspirations are rarely reached except in the largest university libraries. It is far better to work for a system in which researchers at any university can easily become aware of all relevant library materials on their topic anywhere, and for a delivery system which is reasonable and predictable. The costs of immediate access again need to be carefully considered. Waiting for library materials in the smaller university ought to be just another factor in the research process.

\section{ADVANTAGES OF STEADY-STATE}

One advantage of the steady-state library concept is the savings in the area of maintenance cost increases as discussed earlier. Another advantage is the dynamic nature of the collection. In this type of library, most unused and out-of-date books 
are systematically and periodically withdrawn from the collection. New books and those which users have found useful remain. Use of this type of collection is more relevant, useful and inviting, and less frustrating to patrons in their research. Slote (1982) found in one study that a collection which had $20 \%$ of the volumes withdrawn had a $21 \%$ increase in circulation.

\section{IMPLEMENTATION OF STEADY-STATE CONCEPTS}

One method of introducing the steady-state concept to an academic library collection involves firstly, determining the overall optimum size of the collection using the formula recommended by the Association of College and Research Libraries' Standards for College Libraries 1986. The formula provides for an optimum size collection for every smaller academic institution and takes into account the number of faculty, students, undergraduate major and minor fields, master's and doctoral fields.

Secondly, it should be determined how this optimum size library collection breaks down in the individual disciplines. The sizes for each subject area can be derived by taking the number of recommended books for each subject area in Books for College Libraries 1975 and multiplying these by a constant factor to arrive at the overall recommended total. The constant factor needs to be used because there are only 40,000 recommended books in Books for College Libraries 1975, and most optimum size library collections are likely to be much more than this. The size and subject balance of these listings are based on the proportions found in the highly recognized undergraduate libraries at Harvard University and the University of Michigan.

The third step in implementation of steady-state concepts is to determine how each subject area in the institution's library collection measures up to these predetermined optimum levels. Withdrawals or reduced acquisitions may have to be made in some areas and significant additions made in others. A five-year plan for arriving at the optimum size subject collections should be developed based on such institutional factors for each discipline as the average cost per book, the number of faculty/student teaching contacts and the number of circulations the previous year. The speed at which the book collection in that discipline moves toward the optimum size is determined by whether an honours major, major, or minor is offered. Using this formula, the closer subject collections are to optimum size, the greater part usage plays in determining allocations. Stambrook (1983) says that apportionments of library acquisitions budgets ought to be more closely determined by usage.

Selecting material for withdrawal in oversize subject areas can be accomplished through various methods. Primarily, faculty associated with each discipline can be encouraged to be involved in the withdrawal process by having withdrawals reflect in increases in departmental book budget allocations. Making use of their bibliographical expertise gives them some control over what exactly is being 
withdrawn for on-site storage or for discard. The alternative of on-campus storage with the guarantee of prompt retrieval will allay most faculty opposition to the steady-state concept.

An additional method of considering books for withdrawal using clerical staff or student workers can be based on the number of years that books have remained unused. Hall (1985), Kent (1979), Slote (1982), Trochim (1985) and Trueswell (1976) have determined that patterns of past use are highly predictive of future use and can be used as very effective weeding criteria. These materials can be checked against major bibliographies to determine whether items should remain in the collection anyway. Although at this time individual bibliographies are available in machine-readable form, an integrated computerized database of all relevant bibliographies remains yet to be produced. The day is not far off when the whole selection for withdrawal process, including automatic checking against the relevant bibliographies, will be accomplished by computer and a list of books to be withdrawn produced for workers to pull from the shelves. Faculty and librarians need only review material proposed for withdrawal at this point.

If library administration follow these procedures, then a ba!anced steady-state library collection will be achieved. The Standards for College Libraries 1986 recommend that five percent of the total collection be added each year. Another overall five percent can be withdrawn and placed in storage or disposed of.

\section{CONCLUSION}

The steady-state library collection concept is one positive solution to the problems of retrenchment in smaller Canadian universities. A commitment to quality rather than quantity as a measure of the collection's performance is the overall aim of this concept. Library books in a smaller university ought to justify through use the space they occupy on a shelf.

The steady-state library collection concept as a retrenchment alternative needs more research. Studies are needed into difficulties of implementation, and into ways of determining the size of each discipline's book collection. As retrenchment continues, the steady-state academic library collection alternative should be given increasingly closer examination by smaller Canadian universities as a positive solution.

\section{REFERENCES}

American Library Association. Collection Development Committee. (1979). Guidelines for collection development. Chicago: American Library Association.

Association of College and Research Libraries. (1975). Books for college libraries: a core collection of 40,000 titles (2nd ed). Chicago: American Library Association.

Association of College and Research Libraries. (1986, March). Standards for college libraries 1986. College and Research Libraries News. 47, 189-200.

Boll, J. J. (1980). To grow or not to grow. New York: Library Journal. 
Canadian Association of University Teachers. (1987). University libraries - state of crisis. Ottawa Canadian Association of University Teachers.

Cochrane, W.A. (1986). Society's expectations: staying near the customer. In W.A.W. Neilson and C. Gaffields (Eds.) Universities in crisis: a mediaeval institution in the twenty-first century (pp. 29-44). Halifax Institute for Research on Public Policy.

Creaghe, N.S. and D.A. Davis. (1986). Hard copy in transition: an automated storage and retrieval system for low-use library materials. College and Research Libraries, 47, 495-499.

Cuts for academic libraries. (1986, August), Quill and Quire, 52(8), 30-31.

Denis, L.-G. (1985, December). The Management of retrenchment in Canadian academic libraries. Argus, 14, 135-138.

Downes, R. N. (1977). Critical challenges in steady-state financing: a perspective. In Sul H. Lee (Ed.), Library budgeting: critical challenges for the future (pp. 1-14). Ann Arbor, MI: Pierian Press.

Farber, E.I. (1976). Limiting college library growth: bane or boon? In Gore, D. (Ed.), Farewell to Alexandria: solutions to space, growth and performance problems of libraries (pp. 34-43). Westport, CT: Greenwood Press.

Gore. D. (1981, November 15). Curbing the growth of academic libraries: a clear and feasible policy for creating the no-growth collection. Library Journal. 106, 2185-2187.

Gore, D., editor. (1976). Farewell to Alexandria: solutions to space, growth, and performance problems of libraries. Westport, CT: Greenwood Press.

Great Britain. University Grants Committee. (1976). Capital provision for university libraries: report of a working party (Atkinson Report). London: Her Majesty's Stationery Office.

Hall, B.H. (1985). Collection assessment manual for college and university libraries. Phoenix, AZ: Oryx Press.

Hardesty, L. (1981, Fall). Use of library materials at a small liberal arts college. Library Research. 3 , $261-282$.

Harvey, J. F. and P. Spyers-Duran. (1984). Austerity management in academic libraries. Metuchen, NJ: Scarecrow Press.

Kent, A., editor. (1979). Use of library materials: the University of Pittsburgh study. New York: Marcel Dekker.

Nitecki, J. Z. (1984). Creative management in austerity. In J. F. Harvey and P. Spyers-Duran (Eds.) Austerity management in academic libraries (pp. 43-61). Metuchen, NJ: Scarecrow Press.

Slote, S. J. (1982). Weeding library collections - II. Littleton, CO: Libraries Unlimited.

Stambrook, F.G. (1983). Changing climate of opinion about university libraries. Canadian Library Journal, 40, 273-276.

Steele, editor. (1978). Steady-state, zero growth and the academic library. London: Clive Bingley.

Trochim, M. J. (1985). Measuring the book circulation use of a small academic library collection: $a$ manual. Washington, D.C.: Office of Management Studies, Association of Research Libraries.

Trueswell, R.W. (1976). "Growing libraries: who needs them? a statistical basis for the no-growth collection." In D. Gore (Ed.) Farewell to Alexandria - solutions to space, growth, and performance problems of libraries (pp. 72-104). Westport, CT: Greenwood Press. 